\title{
Modulation of ovomucoid-specific oral tolerance in mice fed plant extracts containing lectins
}

\author{
Tanja M. R. Kjær and Hanne Frøkiær* \\ BioCentrum-DTU, Biochemistry and Nutrition, Technical University of Denmark, Lyngby, Denmark
}

(Received 11 October 2001 - Revised 5 July 2002 - Accepted 15 August 2002)

\begin{abstract}
We investigated the effect of feeding extracts of four different legumes (red kidney bean (Phaseolus vulgaris), peanut (Arachis hypogaea), soyabean (Glycine max) and pea (Pisum sativum) on the specific immune response against a food protein. Mice were fed ovomucoid and the specific immune response was evaluated. Ovomucoid fed alone resulted in oral tolerance induction measured as both a reduced ovomucoid-specific spleen cell proliferation and antibody response. Feeding kidney-bean extract prevented induction of oral tolerance to ovomucoid measured as spleen cell proliferation in vitro. Pure kidney-bean lectin also prevented oral tolerance induction, suggesting that lectin in the kidney-bean extract caused inhibition of oral tolerance. Parenteral administration (intravenous and intraperitoneal) of pure kidneybean lectin had no significant influence on oral tolerance induction. Soyabean extract also influenced the immune response against ovomucoid; however, this was not as pronounced as for kidney bean and was only significant $(P<0 \cdot 001)$ for the antibody response. No effect was observed when pea extract was fed and peanut extract had a non-significant effect on induction of oral tolerance and on the general immune response. Plasma antibodies against kidney-bean lectin, but not against the three other legume lectins, were detected. Our current findings show that other dietary components can influence the specific immune response against food proteins. Various dietary components may thus contribute to the onset of adverse immunological responses.
\end{abstract}

Mucosal immunity: Oral tolerance: Legume lectins

Degradation of dietary proteins in the digestive tract is incomplete and a minor amount of even easily degraded proteins reaches the intestine intact. Small amounts of intact dietary protein are absorbed and brought into contact with the immune system. Usually, the gut immune system induces a state of specific tolerance against soluble dietary proteins and this is termed oral tolerance. Induction of oral tolerance is a well-established phenomenon and is believed to be the basis of the prevention of food hypersensitivity (Strobel, 1991).

Several components present in legumes are capable of interfering with the digestion or absorption of other food components. These antinutrients include saponins, phytic acid, lectins, enzyme inhibitors and cyanogenic glycosides (Frøkiær et al. 1997; Liener, 1997). Lectins account for a relatively large amount of legume protein, and as legume lectins are highly resistant towards proteolytic digestion and bind to carbohydrate structures on enterocytes, a larger proportion of lectins than other proteins is absorbed intact (Pusztai et al. 1989; Jørgensen et al. 1998). Interaction of some lectins with carbohydrate on the intestinal wall leads to lesions, severe disruption and abnormal development of the microvilli (Pusztai et al. 1990; Koninkx et al. 1992; Banwell et al. 1993). Lectins may therefore either impair the capacity of the epithelial cells to absorb nutrients from the gut or increase the permeability of the mucosal barrier to macromolecules. Furthermore, as many lectins are strongly mitogenic, the absorbed lectins may affect the immune system by an unspecific stimulation of lymphocytes. Lectins from different legume sources bind different terminal carbohydrates located on various cell types, and therefore the effect on the body metabolism is quite diverse for different lectins.

Lectin from red kidney bean (Phaseolus vulgaris agglutinin, PHA) is highly orally immunogenic; in fact, orally administered PHA resulted in an antibody response at the same level as if given parenterally (de Aizpurua \& Russell-Jones, 1988). However, not only PHA, but also

\footnotetext{
Abbreviations: Ig, immunoglobulin; ip, intraperitoneal; iv, intravenous; OM, ovomucoid; PHA, Phaseolus vulgaris agglutinin (red-kidney-bean lectin); PSA, Pisum sativum agglutinin (pea lectin); SBA, Glycine max agglutinin (soyabean lectin).

* Corresponding author: Dr Hanne Frøkiær, fax +45 45886307, email hf@biocentrum.dtu.dk
} 
other lectins are orally immunogenic. A pea extract containing pea lectin (Pisum sativum agglutinin, PSA) has been reported to enhance the total immunoglobulin (Ig) G antibody level (Martinez et al. 1995). Concanavalin A complexed to ovalbumin has been shown to enhance the formation of anti-ovalbumin $\mathrm{IgE}$ in mice (Gollapudi \& Kind, 1975), and oral ingestion of a lectin from jackfruit (Artocarpus integrifolia) gave an enhanced immunoglobulin E response towards both ovalbumin and the lectin after parenteral challenge with both proteins (Restum-Miguel \& Prouvost-Danon, 1985). More recent studies have also demonstrated that lectins affect the immune response against ovalbumin (Lavelle et al. 2001; Watzl et al. 2001). These results suggest that lectins may promote development of food allergy.

In the present study, we use oral tolerance as a model system for evaluation of the influence of legume extracts on the oral antigenicity of a protein. We show that feeding an extract of red kidney bean leads to inhibition of oral tolerance against ovomucoid (OM), and that this inhibition can be achieved by feeding purified lectin from red kidney bean.

\section{Materials and methods}

\section{Mice and proteins}

Female $(\mathrm{CF} 1 \times \mathrm{BALB} / \mathrm{c}) \mathrm{f}_{1}$ and $\mathrm{BALB} / \mathrm{c}$ mice were obtained from Møllegaard Breeding and Research Centre (M \& E, Ll. Skensved, Denmark) and were used at 8-10 weeks of age. Mice were maintained under standard animal house conditions and were fed rodent chow (Altromin no. 1324, OM- and PHA-free according to the constituent composition and as tested by ELISA; Chr. Petersen A/S, Ringsted, Denmark) ad libitum. The rules for care and use of animal formulated in: 'European Convention for the Protection of Vertebrate Animals Used for Experimental and Other Scientific Purposes' (European Treaty Series, 1986) were followed. The experiments were approved by the Danish Animal Experiments Controlling Body (Dyreforsøgstilsynet). OM (type II-0) and PHA were obtained from Sigma Chemical Co. (St Louis, MO, USA). Legume extracts were prepared from the ground seeds of red kidney bean and peanut (Arachis hypogaea), from a pea-protein concentrate, and from defatted soyabean (Glycine max) flour by overnight extraction in water at $4^{\circ} \mathrm{C}$. The suspensions were centrifuged twice at $1900 \mathrm{~g}$ for $15 \mathrm{~min}$ at $4^{\circ} \mathrm{C}$. The lectin contents of the extracts were determined by sandwich ELISA with monoclonal antibodies produced against the respective lectin, as described by Frøkiær et al. (1994). Concentrations of lectin in the extracts were $1 \mathrm{mg}$ PHA/ml red-kidney-bean extract, $0.2 \mathrm{mg} \mathrm{PSA} / \mathrm{ml}$ pea extract, $1 \mathrm{mg}$ soyabean lectin (Glycine max agglutinin, SBA)/ml soyabean extract and $0.7 \mathrm{mg}$ peanut lectin (Arachis hypogaea agglutinin)/ml peanut extract.

\section{Induction of oral tolerance and oral administration of} lectins

In preliminary studies, oral administration of $10 \mathrm{mg} \mathrm{OM}$ for three consecutive days was shown to result in a significant down-regulation of the immune response against $\mathrm{OM}$ compared with a control group receiving only water. Oral tolerance was therefore induced with $\mathrm{OM}(2 \mathrm{mg} / \mathrm{ml})$ added to the drinking water for three consecutive days, and as mice drank an average amount of $5 \mathrm{ml} / \mathrm{d}$, each animal thus received approximately $10 \mathrm{mg} \mathrm{OM} / \mathrm{d}$. Oral tolerance was induced with $10 \mathrm{mg} \mathrm{OM} / \mathrm{d}$ for $3 \mathrm{~d}$, as one dose of $10 \mathrm{mg}$ was not sufficient to induce oral tolerance against OM. Two groups of mice were included as controls in all experiments: one group was administered OM (referred to as the oral tolerance to OM group) and the other group was administered water alone (referred to as the control group). Additional experimental groups in the first series of experiments were co-administered $\mathrm{OM}$ and legume extract (referred to as the fed legume and OM groups) or administered legume only (referred to as the fed legume only groups). In the next experiment, groups were fed pure PHA and OM (referred to as the fed pure PHA and OM group) and kidney bean and OM. In a third experiment, groups of mice were injected with PHA either intraperitoneally (ip) or intravenously (iv) (referred to as the parenterally injected PHA and fed OM groups). One group of mice was injected iv in the tail vein and another group ip. Both groups were injected with $100 \mu \mathrm{g}$ pure PHA/d on the same $3 \mathrm{~d}$ they were fed OM.

All experimental compounds were administered by the drinking water and mice were maintained on the experimental regimen for $3 \mathrm{~d}$ (days 1-3). Legume extract was administered undiluted instead of drinking water and dependent on the extract, each mouse consumed either $5.0 \mathrm{mg}$ PHA, $1.0 \mathrm{mg}$ PSA, $3.5 \mathrm{mg}$ peanut lectin, or $5.0 \mathrm{mg}$ $\mathrm{SBA} / \mathrm{d}$ for $3 \mathrm{~d}$. Mice administered pure PHA received approximately $5.0 \mathrm{mg} \mathrm{PHA} / \mathrm{d}$ for $3 \mathrm{~d}$ together with $\mathrm{OM}$. $\mathrm{OM}$ was added to the undiluted legume extract in groups co-administered OM and legume extracts.

\section{Parenteral immunization and bleeding}

In order to visualize oral tolerance, all mice from all groups were immunized ip with $10 \mu \mathrm{g} \mathrm{OM}$ in complete Freund's adjuvant (Difco Laboratories, Detroit, MI, USA) $10 \mathrm{~d}$ after the last feeding day (day 13) and with $10 \mu \mathrm{g}$ OM in Freund's incomplete adjuvant (Difco Laboratories) 2 weeks later (day 27), where day 1 refers to the first day of feeding. Water-oil emulsions of Freund's incomplete adjuvant and Freund's complete adjuvant were prepared by mixing the oil phase thoroughly on a vortex mixer and adding the aqueous phase drop by drop (oil-water $1: 1, \mathrm{v} / \mathrm{v})$. Mice were immunized with a total volume of $100 \mu \mathrm{l}$. Blood was collected from the retro-orbital venous plexus on days $0,4,13,27$ and 34 using heparinized micropipettes and stored at $-20^{\circ} \mathrm{C}$.

\section{Measurement of ovomucoid-specific antibodies by ELISA}

Antibody titres were determined by ELISA. Blood samples from each mouse were serially diluted on microtitre plates (Maxisorp; Nunc, Roskilde, Denmark) coated with OM (30 ng per well) in carbonate buffer ( $\mathrm{pH} \mathrm{9.6)} \mathrm{and} \mathrm{incubated}$ for $1 \mathrm{~h}$ at room temperature. OM used for coating was 
purified as described by Ebbehoj et al. (1995). After washing, peroxidase-conjugated rabbit anti-mouse immunoglobulins (Dako, Glostrup, Denmark) diluted 1:1000 were added and plates were incubated for $1 \mathrm{~h}$. OM-specific IgG1 and $\operatorname{IgG} 2 \mathrm{a}$ were detected with rabbit anti-mouse $\operatorname{IgG} 1$ and IgG2a antibodies (Zymed, San Francisco, CA, USA) followed by peroxidase-conjugated swine anti-rabbit Ig (Dako). $\mathrm{H}_{2} \mathrm{O}_{2}$ and tetramethyl benzidiene (Merck, Darmstadt, Germany) were used as substrates and the reaction was stopped by the addition of $2 \mathrm{M}$-phosphoric acid. Microtitre plates were assayed spectrophotometrically at $450 \mathrm{~nm}$ using $630 \mathrm{~nm}$ as reference on an ELISA reader (Bio-kinetics reader, EL 340; Biotek Instruments, Winoaski, VT, USA). On each plate, an internal standard, a monoclonal antibody against OM, was included. Each blood sample was measured at least twice. Sample titres were calculated by four variable analysis (Kineticalc software, version 2.13; Biotek Instruments) based on the least dilution giving an optical density of 0.2 above background. Titres were $\log _{2}$-transformed before plotting and statistical analysis.

\section{Measurement of lectin-specific antibodies by ELISA}

Some lectins are orally immunogenic and antibodies against the fed lectins can be detected in the blood from fed animals (Pusztai, 1993). PHA is highly orally immunogenic; in fact, orally administered PHA is reported to mount an antibody response at the same level as if given parenterally (de Aizpurua \& Russell-Jones, 1988). Measurement of lectin-specific antibodies was done as described earlier for OM-specific antibodies, except for coating, which was done with the relevant lectin (100 ng per well).

\section{Measurement of antigen-specific in vitro cell proliferation}

Cellular immunity was evaluated as antigen-specific proliferation of spleen cell preparations measured as incorporation of $\left[{ }^{3} \mathrm{H}\right]$ thymidine during the last $24 \mathrm{~h}$ of incubation. Preparation of cellular suspensions and proliferation assays were prepared as described by Kruisbeek \& Shevach $(1991,1993)$. In short, spleen cells were collected $7 \mathrm{~d}$ after the last immunization and a single cell suspension was prepared from each mouse spleen; cells were treated with ammonium chloride $(8.3 \mathrm{~g} / \mathrm{l}$, incubated for $5 \mathrm{~min}$ on ice) for removal of erythrocytes and washed with Dulbecco's modified Eagle medium (Gibco, Life Technologies, Paisley, Scotland, UK) supplemented with $10 \mathrm{ml}$ penicillin-streptomycin (100 IU penicillin and $100 \mu \mathrm{g}$ streptomycin $/ \mathrm{ml}) / \mathrm{l}$. Viable cells $\left(8 \times 10^{5}\right)$ were cultured in triplicate in $200 \mu \mathrm{l}$ X-VIVO 10 (serum free medium; Bio Whitaker, Walkersville, MD, USA) supplemented with $3.9 \mathrm{~mm}$-glutamine and penicillinstreptomycin $(10 \mathrm{ml} / \mathrm{l})$ with and without $50 \mu \mathrm{g} \mathrm{OM} / \mathrm{ml}$. $50 \mu \mathrm{g} \mathrm{OM} / \mathrm{ml}$ was determined to be optimal for lymphocyte proliferation. $\left[{ }^{3} \mathrm{H}\right]$ Thymidine $\quad(37.0 \mathrm{kBq} / \mathrm{ml}$; Amersham International, Amersham, Bucks., UK) was added after incubation for $3 \mathrm{~d}$ in humidified $\mathrm{CO}_{2}$-air $(5: 95, \mathrm{v} / \mathrm{v})$. Cells were harvested $24 \mathrm{~h}$ later onto glass fibre filters using a semi-automatic cell harvester (Nunc).
The amount of incorporated thymidine was determined on a Tri-Carb ${ }^{\circledR}$ Liquid Scintillation analyser (Packard Instrument Co., Meriden, CT, USA).

\section{Statistical analysis}

Results are presented as arithmetic means with their standard errors for each group of mice. Significant differences between groups were determined by Student's two-tailed $t$ test for unpaired samples and $P$ values $<0.05$ were considered to be statistically significant. Multiple comparison procedures were done by Newman-Keuls multiple comparison tests after an $F$ test (ANOVA) had identified that a significant difference existed (Montgomery, 1991); the statistical analysis was done with GraphPad Prism 3.0 software (GraphPad Inc., San Diego, CA, USA). Induction of oral tolerance was defined as a statistically significantly reduced antigen-specific spleen cell proliferation or antibody response in $\mathrm{OM}$ or in OM plus legume extract-fed mice compared with the response of the control group. Criterion for inhibition of oral tolerance by oral administration of legume extracts and/or pure PHA was a statistically significant enhanced response in OM plus legume extract-fed mice compared with mice fed OM alone.

\section{Results}

\section{Induction of unresponsiveness to ovomucoid}

The experiments on the influence of legume extracts on the immune response against a dietary protein were based on oral tolerance induction with $\mathrm{OM}$. OM was used since it is known to be one of the major allergens in egg albumin (Matsuda \& Nakamura, 1993; Bernhisel-Broadbent et al. 1994) and because the protein is highly resistant towards proteolytic digestion. Oral tolerance against $\mathrm{OM}$ was induced in mice fed pure OM demonstrated by a statistically significant reduction in cellular proliferation in vitro and in antibody response compared with control mice (Figs. 1 and 2). Blood samples were also analysed for OM-specific IgG1 and $\operatorname{IgG} 2 \mathrm{a}$ antibodies and in OM-fed groups both isotypes were significantly reduced compared with the control mice (results not shown), indicating that both T-helper cell types 1 and 2 were tolerised (Snapper \& Paul, 1987).

\section{Influence of oral administration of legume extracts on the induction of oral tolerance against ovomucoid}

Four different legume extracts were fed together with OM. Administration of pea extract together with OM had no influence on oral tolerance induction against $\mathrm{OM}$ (Figs. 1(a) and 2(a)), since groups fed OM plus pea extract had the same response as OM-fed mice. On the other hand, administration of kidney-bean extract and OM resulted in a proliferation response that was significantly enhanced compared with mice fed OM (Fig. 1(b)). Mice fed OM alone had a mean proliferative response significantly $(P<0.05)$ different from mean values of the other three groups (fed kidney bean plus OM, fed kidney bean and control). The 
OM-specific antibody response was significantly $(P<0 \cdot 05)$ reduced in kidney-bean-extract- and OM-fed mice when compared with control mice, although the significance level was not as pronounced for mice fed OM and kidney bean as for mice fed $\mathrm{OM}$ alone (Fig. 2(b)). However, although the OM-fed group and the OM and kidney beanfed group were not equally reduced, they did not differ significantly. Thus, oral tolerance is induced in mice receiving kidney-bean extract and OM when measured as OM-specific antibodies. When OM and peanut extract were co-administered, oral tolerance was not induced, although the proliferation response was not significantly different from the OM-fed mice (Fig. 1(c)). Mice fed peanut extract alone also had a diminished OM-specific response compared with control mice and this hinders interpretation of the influence of peanut extract on oral tolerance induction. OMspecific antibody titres were not significantly influenced when peanut extract plus OM were fed compared with the OM fed group and oral tolerance was induced in this group (Fig. 2(c)). When soyabean was administered together with $\mathrm{OM}$, oral tolerance measured as proliferation was not induced; however, the response of OM-fed mice and OM and soybean-fed mice were not significantly different either (Fig. 1(d)). The OM-specific antibody response of mice fed $\mathrm{OM}$ and soyabean was significantly $(P<0 \cdot 001)$ increased compared with mice fed OM alone (Fig. 2(d)), although oral tolerance was still induced in this group, both when compared with the soybean-fed group and controls. Blood samples from all groups were analysed for OM-specific IgG1 and IgG2a antibodies and it was not possible to detect any differences in the response of extract- or extract and OM-fed mice (results not shown).

Mice receiving legume extracts did not loose weight and the intestine had no macroscopic signs of injury.
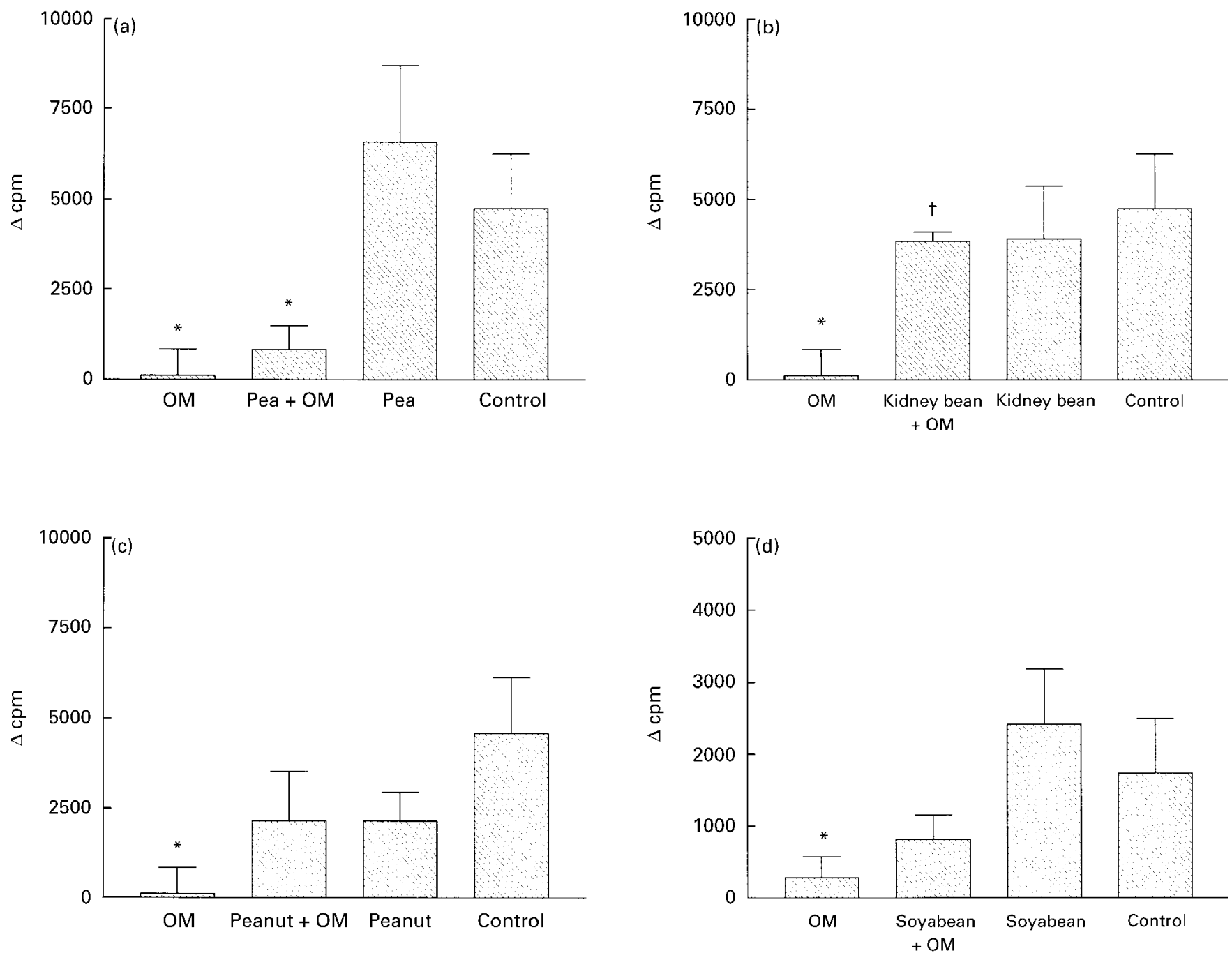

Fig. 1. Effects of feeding four legume extracts (pea (Pisum sativum), red kidney bean (Phaseolus vulgaris), peanut (Arachis hypogaea) and soyabean (Glycine max)) and ovomucoid (OM) on OM-specific proliferation of spleen cells. Legume extracts and/or OM were administered by the drinking water. Control mice received water only. Mice were fed for $3 \mathrm{~d}$ and immunized twice with OM. Proliferation was measured as incorporation of $\left[{ }^{3} \mathrm{H}\right]$ thymidine in spleen cells from individual mice stimulated with and without OM. For details of diets and procedures, see pp. $672-673$. Values are means for four to six mice per group with their standard errors shown by vertical bars. Mean values were significantly different from those of the control group: ${ }^{\star} P<0.05$. Mean value was significantly different from that of the OM-fed group: $\dagger P<0.05$. 
Detection of lectin-specific antibodies in mice fed kidneybean extract

The level of PHA-specific antibodies was elevated in blood samples from most of the mice fed kidney-bean extract (Fig. 3). No other groups showed elevated levels of antibodies against the respective lectins (results not shown).

\section{Influence of oral administration of pure Phaseolus vulgaris agglutinin on the induction of oral tolerance against ovomucoid}

As PHA could be the component in the kidney-bean extract responsible for the enhanced OM-specific proliferative response in $\mathrm{OM}$ and kidney-bean-extract-fed mice, a new feeding trial was performed in which a group fed OM and pure PHA was included. In this experiment, groups of mice were fed $5 \mathrm{mg}$ pure $\mathrm{PHA} / \mathrm{d}$ or the corresponding amount of PHA was administered via the kidney-bean extract as in the former experiment.

As illustrated in Fig. 4(a), oral tolerance was not induced when pure PHA was fed together with OM. There was no difference in OM-specific proliferation between groups that were fed pure PHA and OM or kidney-bean extract and OM. The group fed kidney-bean extract plus OM and the group fed pure PHA plus OM both had responses that were not significantly different from the control.

Like kidney-bean extract, orally administered pure PHA had no significant effect on the antibody responses against OM (Fig. 4(b)). Hence, comparable results were obtained when PHA was fed alone or as a component in an extract.
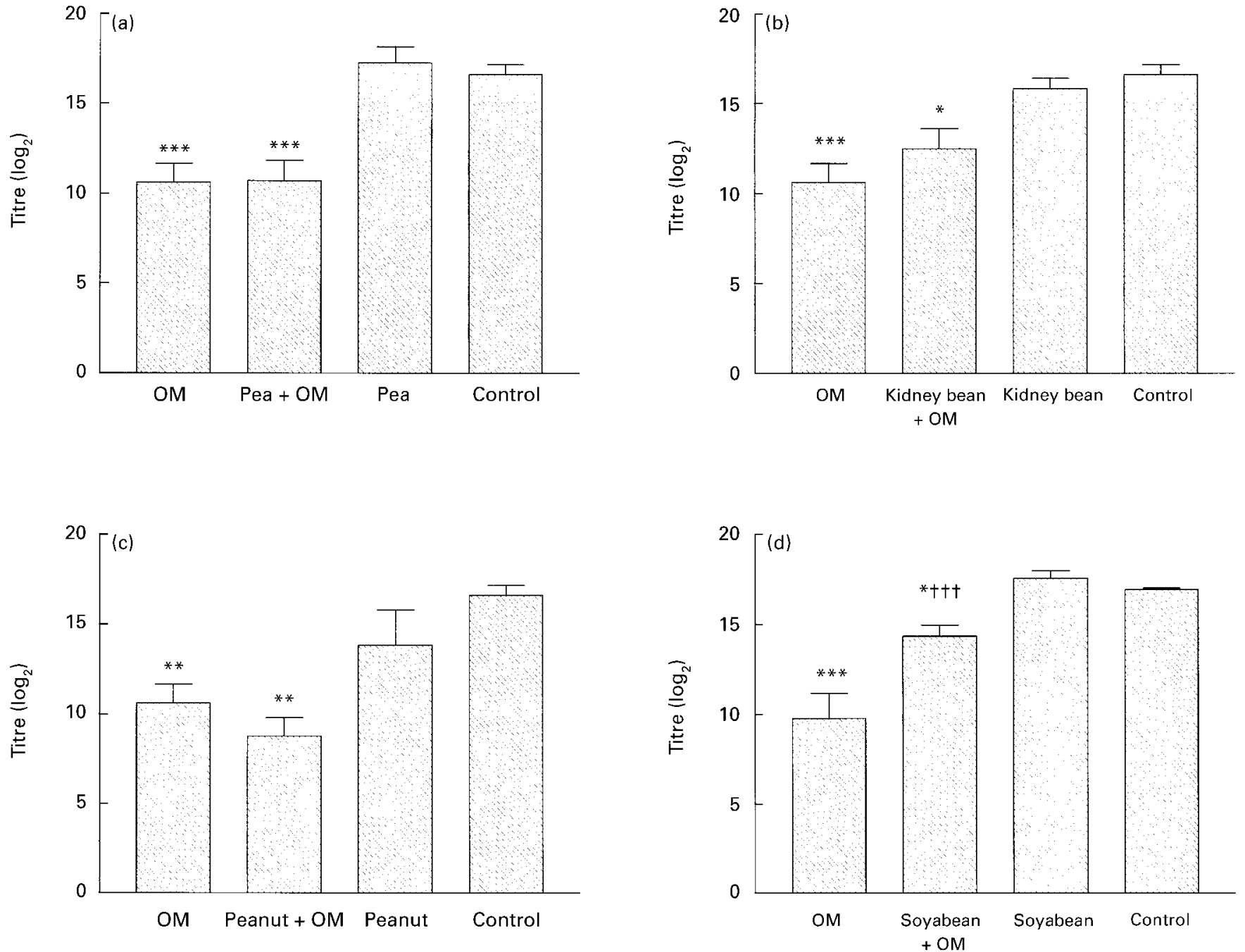

Fig. 2. Effects of feeding four legume extracts (pea (Pisum sativum), red kidney bean (Phaseolus vulgaris), peanut (Arachis hypogaea) and soyabean (Glycine max)) on ovomucoid (OM)-specific antibodies in plasma. Mice were fed OM, various legume extracts, or OM and a legume extract. Control mice received water only. Mice were fed for $3 \mathrm{~d}$, immunized twice with OM and blood was collected 1 week after the last immunization. For details of diets and procedures, see pp. 672-673. Values are means for four to six mice per group with their standard errors shown by vertical bars. Mean values were significantly different from those of the control group: ${ }^{\star} P<0.05,{ }^{* \star} P<0.01,{ }^{* \star *} P<0.001$. Mean value was significantly different from that of the OM-fed group: $\dagger+\dagger P<0.001$. 
Influence of parenteral administration of Phaseolus vulgaris agglutinin on ovomucoid-specific oral tolerance induction

To investigate whether the observed effect of orally administered PHA was local or systemic, $100 \mu \mathrm{g}$ pure PHA in PBS was injected iv and ip in groups of mice fed OM simultaneously (Fig. 5). The amount of PHA injected was larger than the amount of PHA that could be detected in blood samples from mice fed PHA $1 \mathrm{~h}$ previously. Iv and ip administration of PHA had no influence on oral tolerance induction, as both iv- and ip-injected groups had OM-specific cell proliferation and antibody responses on the same level as mice fed OM alone.

\section{Discussion}

In the present study, we have demonstrated that an extract of red kidney bean can, if fed simultaneously with a dietary protein, prevent induction of oral tolerance against that protein. It seems reasonable to conclude that the active component of the kidney-bean extract is PHA, as there was no difference in the immune responses after feeding pure PHA or an extract from kidney bean containing PHA. Likewise, the effect of three other legume extracts was investigated. Pea extract did not influence the induction of oral tolerance, whereas feeding of a peanut extract had a general influence on the immune response, which made interpretation of the effect on oral tolerance induction against $\mathrm{OM}$ difficult. Soyabean extract also had an influence on oral tolerance induction; this was, however, not as pronounced as for kidney bean and was, in contrast to kidney bean, only significant $(P<0 \cdot 001)$ for the antibody response.

It was possible to detect antibodies against native PHA after feeding kidney-bean extract, demonstrating that PHA is a strong oral immunogen that is absorbed intact and gets into contact with the immune system either locally or systemically. Lavelle et al. (2000) found that oral delivery of PHA elicits a strong systemic lectin-specific antibody response, but a modest local antibody response. Generation of PHA-specific antibodies in kidney bean-fed mice could be due to agglutination of erythrocytes after absorption of PHA to the blood or simply by binding of PHA to the surface of erythrocytes.

The effect of PHA on the OM-specific response may be caused by a local stimulation of lymphocytes in the gutassociated lymphoid tissue or by a systemic stimulation of lymphocytes in the spleen after absorption of intact PHA to the blood. Neither iv nor ip injection of PHA simultaneously with OM feeding affected the OM-specific immune response. A small proportion of orally administered protein escapes digestion and is absorbed intact (Strobel \& Mowat, 1998). Since orally administered antigen can be detected in the bloodstream within $1 \mathrm{~h}$ after antigen feeding (Furrie et al. 1995), mice were injected and fed at the same time in the present study. The amount of protein absorbed intact is dependent on the protein and varies between 0.001 and $1 \%$ of the administered dose (Strobel \& Mowat, 1998), and lectins generally are absorbed to a greater degree than other dietary proteins (Pusztai et al. 1989; Jørgensen et al. 1998). In the present experiment, iv injection of $100 \mu \mathrm{g}$ corresponds to $2 \%$ orally administered PHA (approximately $5 \mathrm{mg}$ ). If the effect of PHA is

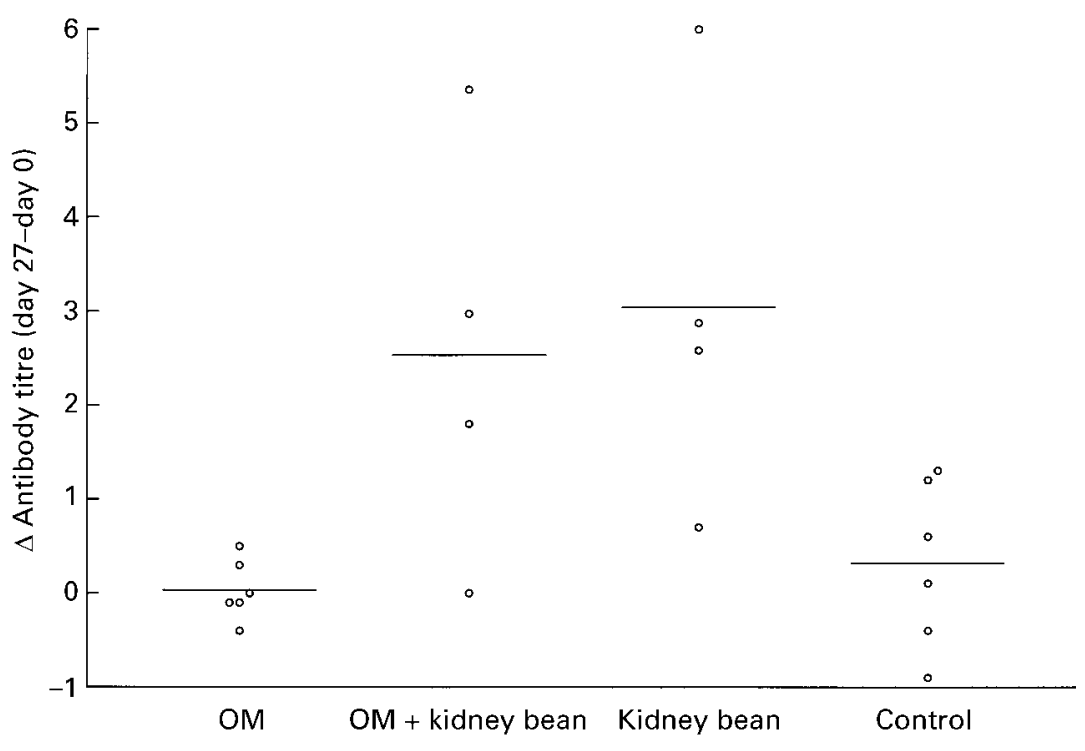

Fig. 3. Effects of feeding red-kidney-bean (Phaseolus vulgaris) extract on haemagglutinin (PHA) specific antibodies in plasma. Mice were fed ovomucoid (OM) or kidneybean extract alone or both OM and kidney-bean extract. Control mice received water only. Blood was collected on day 0 and 27 . For details of diets and procedures, see pp. 672-673. Values are antibody titre on day 27 - antibody titre on day 0 for each mouse. Horizontal lines represent the mean values for four to six mice. Titres are expressed as the increase in antibodies against PHA, as PHA may bind to carbohydrate on the detection immunoglobulins and therefore titres on day 0 vary between mice. 
due to the presence of PHA in circulation, the injected amount should thus be sufficient to achieve such an effect. Accordingly, as iv and ip injections have no influence on the OM-specific response, it appears that PHA acts locally either directly on the immune system by a non-specific stimulation of lymphocytes or antigen-presenting cells in the gut-associated lymphoid tissue or by affecting the integrity of the intestinal epithelium and hence absorption of dietary antigens.
In contrast to our present findings, intranasal administration of PHA plus ovalbumin has been demonstrated to elicit a lectin-specific antibody response, but did not change the ovalbumin-specific mucosal or systemic antibody response (Lavelle et al. 2001). Nevertheless, the findings of Lavelle et al. (2001) are in agreement with our present findings, since PHA had no significant effect on the systemic OM-specific antibody response in the present study. Differences in routes of administration may have
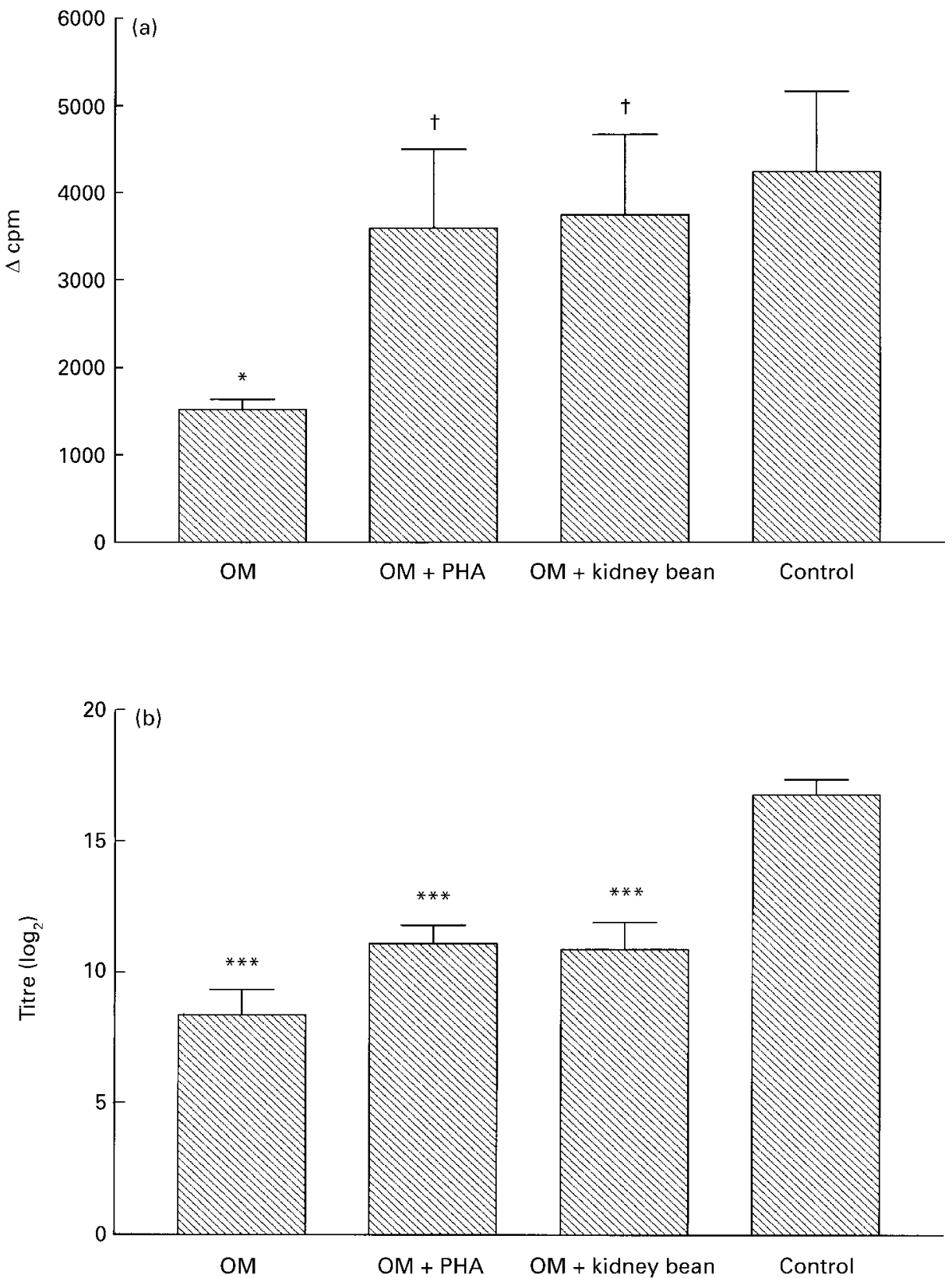

Fig. 4. Effects of feeding red-kidney-bean (Phaseolus vulgaris) haemagglutinin (PHA) on ovomucoid (OM)-specific proliferation of spleen cells and OM-specific antibodies in plasma. Mice were fed either OM alone or PHA and OM as indicated under each bar. PHA was given either pure or as a component in a kidney-bean extract. The control group received water only. Mice were fed for $3 d$ (days $1-3$ ) and immunized twice with OM (day 13 and 27). Spleen cells were collected $7 \mathrm{~d}$ after the last immunization. Blood was collected 1 week after the second immunization (day 34). For details of diets and procedures, see pp. 672-673. Proliferation was measured as incorporation of $\left[{ }^{3} \mathrm{H}\right]$ thymidine in spleen cells from individual mice cultured with and without OM. Values are means for five mice per group with their standard errors shown by vertical bars. Mean values were significantly different from those of the control group: ${ }^{\star} P<0.05,{ }^{\star \star \star} P<0.001$. Mean value was significantly different from that of the OM-fed group: $† P<0.05$. 
impact on the outcome of an immune response, since there are differences in the nasal and the gut lymphoid tissue. In another study addressing the same issue, oral administration of wheatgerm agglutinin was shown to decrease ovalbumin-induced antibody responses in Brown Norway rats, but had no effect on the general proliferation response (Watzl et al. 2001). However, the Brown Norway rat system is very different from our model system: an immune response was induced in the Brown Norway rats after feeding, whereas in our present system, mice were hyporesponsive.

$\mathrm{OM}$ is a glycoprotein with a high degree of glycosylation $(25 \%)$ and it has been reported that PHA can be isolated by means of polymerised OM (Goncalves \& Costa, 1995). This raises the possibility that OM and PHA were complexed at the time of ingestion. Whether large complexes of $\mathrm{OM}$ and PHA are formed under the conditions of the present study was analysed by capillary
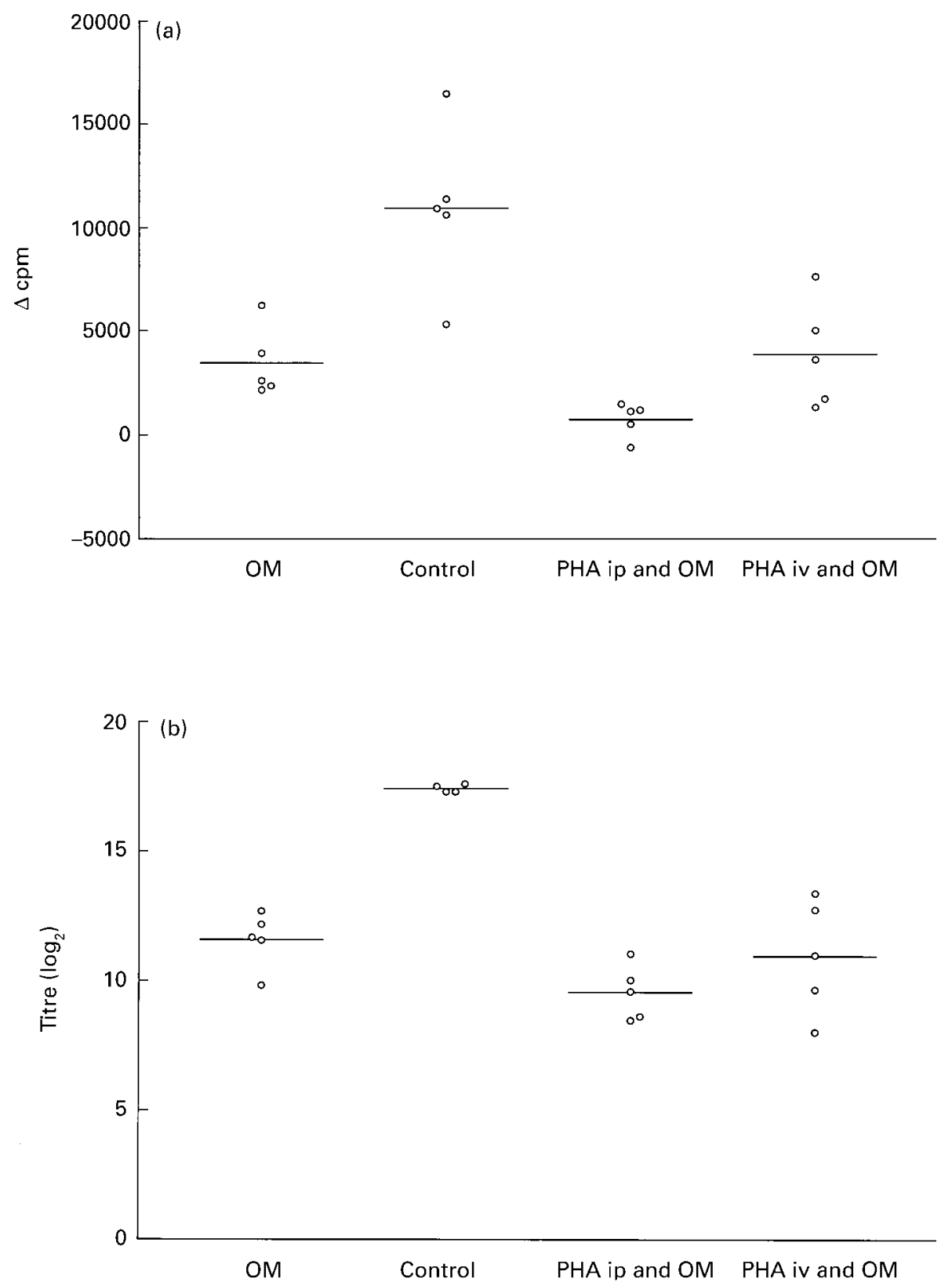

Fig. 5. Effects of intravenous (iv) and intraperitoneal (ip) injection of red-kidney-bean (Phaseolus vulgaris) haemagglutinin (PHA) on ovomucoid (OM)-specific proliferation of spleen cells and on development of OM-specific antibodies in mice. One group of mice received OM orally $(\mathrm{OM})$, control mice received water alone, another group received PHA ip and OM orally (PHA ip and OM) and the last group received PHA iv and OM orally (PHA iv and OM). Mice were fed for $3 \mathrm{~d}$; the mice receiving PHA iv or ip were injected for the same $3 \mathrm{~d}$. Mice were immunized twice and spleen cells and blood were collected $7 \mathrm{~d}$ after the last immunization. Proliferation was measured as incorporation of [ ${ }^{3} \mathrm{H}$ ]thymidine in spleen cells from individual mice stimulated with and without OM. For details of diets and procedures, see pp. 672-673. Horizontal lines represent the mean values of five mice. 
electrophoresis and it was not possible to detect complex formation.

SBA is known to bind strongly to the enterocytes of human subjects (Koninkx et al. 1992) and rats (Pusztai et al. 1990) and may thereby change the permeability of the intestinal wall, but SBA has little mitogenic activity towards mice lymphocytes in vitro (Frøkiær et al. 1997). A soyabean extract containing SBA has, in the present study, been shown to influence oral tolerance induction in vivo. In accordance with this, it has been reported that ip injection of SBA leads to an increase in the T-helper lymphocyte population in vivo (Benjamin et al. 1997). In the present experiment, co-administration of a sugar specific for SBA reversed the observed modulation of the OM-specific antibody response in soyabean plus OM-fed mice (results not shown), suggesting that SBA is responsible for the observed effect.

We have previously shown that PSA is a more potent stimulator of lymphocytes than PHA in vitro (Frøkiær et al. 1997). The presence of PSA in an orally administered extract had no influence on the induction of oral tolerance against OM. Binding of lectin to the gut wall leads to an increased absorption of lectin (Pusztai, 1993) and binding by some lectins will cause degeneration of the intestinal wall. PSA, however, does not bind as strongly as PHA to the gut wall and does not cause degeneration of the intestinal wall (Koninkx et al. 1992). In the present study, there were no macroscopic signs of injury to the intestine in any of the lectin-fed mice. Mice were fed a relatively large amount of lectin, but only for $3 \mathrm{~d}$. Peas have been shown to influence the general immune response in mice when given orally (Martinez et al. 1995), yet in the study by Martinez et al. (1995) mice were fed for 3 weeks and the effects of dietary lectins after medium- and short-term exposure may vary extensively.

Administration of a mixture of proteins or impure preparations of protein can influence oral tolerance as seen by Stokes et al. (1983) and Okumura et al. (1994). Such mixtures of proteins might affect the absorption of the actual protein as well as the immune response against the protein. In the present study, it was not simply the presence of a mixture of different proteins in the kidney-bean extract that affected oral tolerance induction, but merely the action of one specific component (e.g. PHA) in the mixture. When administrating another mixture of proteins, as when pea extract was fed together with OM, it was possible to induce oral tolerance when a mixture of proteins was administered orally. At present, it is not known how the amount of total protein in the gut affects the absorption of one specific protein.

A weakness of the model of oral tolerance in analysing the influence of other food components on a specific immune response is that inhibition of oral tolerance might not be complete and a response in between the control group and the oral tolerance-induced group might be obtained. Therefore, the difference between either the control group or the OM-fed group may not be significant as compared with the $\mathrm{OM}$ plus legume extract fed-group. This was seen in the present study, when feeding peanut and soyabean extract together with OM (Fig. 1(c) and (d)) and in kidney-bean-extract-fed mice (Fig. 2(b)).
Feeding high doses of pure protein is believed to induce oral tolerance characterized by, among other mechanisms, anergy of T-helper cells (Hirahara et al. 1995; Inada et al. 1997). Induction of anergy is a consequence of an absence of co-stimulation during T-cell activation. Early reports indicated that T-cell activation by PHA is mediated through binding of PHA to the T-cell receptor (Chilson et al. 1984) leading to interleukin 2 receptor and interleukin 2 production (Leivestad et al. 1988). However, the exact mechanisms of PHA on the cells of the immune system remain to be elucidated. We believe that PHA may locally activate T-helper cells that in the absence of PHA are tolerised due to missing co-stimulation signals. Activation of some subsets of T-helper cells may explain the finding that oral tolerance is inhibited when measured as cell proliferation, but not measured as antibodies. PHA has been demonstrated to be predominantly T-cell stimulating (Miller, 1983), but in PHA-stimulated human lymphocyte cultures, B cells also underwent mitosis (Knuutila \& Kovanen, 1987; Kovanen \& Knuutila, 1989). Recently, lectins have been reported to induce release of interleukin 4 and 13 (Haas et al. 1999), which can switch the immune response to a T-helper cell 2 response (Ryan, 1997) and Lavelle et al. (2000) have found that oral administration of PHA mainly stimulates production of lectin-specific IgG1 antibodies in the blood and hence a systemic T-helper cell type 2 response. In the present study, we measured the antibody response against a co-fed protein, OM, and it was not possible to detect a deviation of the OM-specific immune response towards a T-helper cell type 1 or 2 response in lectin-fed animals.

In conclusion, our present study shows that oral tolerance can be modulated by simultaneous oral administration of a dietary plant lectin and thus supports our hypothesis that external factors, such as food components, can influence the induction of oral tolerance and thereby may influence the immune status.

\section{Acknowledgements}

This work was supported by a grant from the Technical University of Denmark and by Centre for Advanced Food Research. We thank Dorthe Nielsen, Lone Hendriksen and Thea Gärtner for skilled technical assistance.

\section{References}

Banwell JG, Howard R, Kabir I, Adrian TE, Diamond RH \& Abramowsky C (1993) Small intestinal growth caused by feeding red kidney bean phytohemagglutinin lectin to rats. Gastroenterology 104, 1669-1677.

Benjamin CF, Figueiredo RC, Henriques MG \& Barja-Fidalgo C (1997) Inflammatory and anti-inflammatory effects of soybean agglutinin. Brazilian Journal of Medical and Biological Research 30, 873-881.

Bernhisel-Broadbent J, Dintzis HM, Dintzis RZ \& Sampson HA (1994) Allergenicity and antigenicity of chinken egg ovomucoid (Gal d III) compared with ovalbumin (Gal d I) in children with egg allergy and in mice. Journal of Allergy and Clinical Immunology 93, 1047-1059.

Chilson OP, Boylston AW \& Crumpton MJ (1984) Phaseolus 
vulgaris phytohaemagglutinin (PHA) binds to the human $\mathrm{T}$ lymphocyte antigen receptor. EMBO Journal 3, 3239-3245.

de Aizpurua HJ \& Russell-Jones GJ (1988) Oral vaccination. Identification of classes of proteins that provoke an immune response upon oral feeding. Journal of Experimental Medicine 167, 440-451.

Ebbehoj K, Dahl AM, Frokiaer H, Norgaard A, Poulsen LK \& Barkholt V (1995) Purification of egg-white allergens. Allergy 50, 133-141.

European Treaty Series (1986) European convention for the protection of vertebrate animals used for experimental and other scientific purposes. Strasbourg: ETS no. 123, 18.III.

Frøkiær H, Hørlyck L, Barkholt V, Sørensen H \& Sørensen S (1994) Monoclonal antibodies against soybean and pea proteinase inhibitors: characterization and applications for immunoassays in food processing and plant breeding. Food and Agricultural Immunology 6, 63-72.

Frøkiær H, Jørgensen TMR, Rosendal A, Tonsgaard MC \& Barkholt V (1997) Antinutritional and allergenic proteins. In Antinutrients and Phytochemicals in Food, pp. 44-60 [F Shahidi, editor]. Washington, DC: American Chemical Society.

Furrie E, Turner MW \& Strobel S (1995) Partial characterization of a circulating tolerogenic moiety which, after a feed of ovalbumin, suppresses delayed-type hypersensitivity in recipient mice. Immunology 86, 480-486.

Gollapudi VS \& Kind LS (1975) Enhancement of reaginic antibody formation in the mouse by concanavalin A. International Archives of Allergy and Applied Immunology 48, 94-100.

Goncalves RB \& Costa CP (1995) Isolation of the lectin and an L4 isolectin from Phaseolus vulgaris by affinity chromatography on insoluble ovomucoid. Brazilian Journal of Medicinal and Biological Research 28, 191-194.

Haas H, Falcone FH, Schramm G, Haisch K, Gibbs BF, Klaucke J, Poppelmann M, Becker WM, Gabius HJ \& Schlaak M (1999) Dietary lectins can induce in vitro release of IL-4 and IL-13 from human basophils. European Journal of Immunology 29, 918-927.

Hirahara K, Hisatsune T, Nishijima K, Kato H, Shiho O \& Kaminogawa S (1995) CD4 + T cells anergized by high dose feeding establish oral tolerance to antibody responses when transferred in SCID and nude mice. Journal of Immunology 154, 6238-6245.

Inada S, Yoshino S, Haque MA, Ogata Y \& Kohashi O (1997) Clonal anergy is a potent mechanism of oral tolerance in the suppression of acute antigen-induced arthritis in rats by oral administration of the inducing antigen. Cellular Immunology 175, 67-75.

Jørgensen TMR, Mikkelsen T, Tonsgaard MC, Rossen M, Sørensen S \& Frøkiær H (1998) The influence of plant lectins on immune response against another dietary protein. In Plant Proteins from European Crops. Food and Non-Food Applications, pp. 198-202 [J Gueguenand and Y Popineau, editors]. Berlin, Heidelberg: Springer-Verlag.

Knuutila S \& Kovanen PE (1987) Relative proportions of mitotic $\mathrm{T}$ and B cells in PHA-stimulated lymphocyte cultures. Cancer Genetic Cytogenetics 29, 151-154.

Koninkx JF, Hendriks HG, van Rossum JM, van den Ingh TS \& Mouwen JM (1992) Interaction of legume lectins with the cellular metabolism of differentiated Caco-2 cells. Gastroenterology 102, 1516-1523.

Kovanen PE \& Knuutila S (1989) Mitotic cells in different lymphocyte subsets in unfractionated cultures stimulated by phytohaemagglutinin or pokeweed mitogen. Hereditas 110, 69-74.

Kruisbeek AM (1993) Isolation of mouse mononuclear cells. In Current Protocols in Immunology, pp. 3.1.2-3.1.5 [JE Coligan, AM Kruisbeek, DH Magulies, EM Shevachand and W Strober, editors]. New York: Greene Publishing and Wiley-Interscience.
Kruisbeek AM \& Shevach EM (1991) Proliferative assays for T cell function. In Current Protocols in Immunology, pp. 3.12.1-3.12.14 [JE Coligan, AM Kruisbeek, DH Magulies, EM Shevachand and W Strober, editors]. New York: Greene Publishing and Wiley-Interscience.

Lavelle EC, Grant G, Pusztai A, Pfüller U \& O'Hagan DT (2000) Mucosal immunogenicity of plant lectins in mice. Immunology 99, 30-37.

Lavelle EC, Grant G, Pusztai A, Pfuller U \& O'Hagan DT (2001) The identification of plant lectins with mucosal adjuvant activity. Immunology 102, 77-86.

Leivestad T, Halvorsen R, Gaudernack G \& Thorsby E (1988) Requirements for phytohaemagglutinin activation of resting pure CD4+ and CD8+ T cells. Scandinavian Journal of Immunology 27, 565-572.

Liener IE (1997) Plant lectins: properties, nutritional significance, and function. In Antinutrients and Phytochemicals in Food, pp. 31-43 [F Shahidi, editor]. Washington, DC: American Chemical Society.

Martinez JA, Esparza ML \& Larralde J (1995) Immunological changes in growing mice fed on diets containing casein or peas (Pisum sativum var. Belinda) as the source of protein. British Journal of Nutrition 73, 87-97.

Matsuda T \& Nakamura R (1993) Molecular structure and immunological properties of food allergens. Trends in Food Science and Technology 4, 289-293.

Miller K (1983) The stimulation of human B and T lymphocytes by various lectins. Immunobiology 165, 132-146.

Montgomery DC (1991) Design and Analysis of Experiments, 3rd ed., New York: John Wiley \& Sons.

Okumura S, McIntosh K \& Drachman DB (1994) Oral administration of acetylcholine receptor: effects on experimental myasthenia gravis. Annals of Neurology 36, 704-713.

Pusztai A (1993) Dietary lectins are metabolic signals for the gut and modulate immune and hormone functions. European Journal of Clinical Nutrition 47, 691-699.

Pusztai A, Ewen SW, Grant G, Peumans WJ, van Damme EJ, Rubio L \& Bardocz S (1990) Relationship between survival and binding of plant lectins during small intestinal passage and their effectiveness as growth factors. Digestion 46, Suppl. 2, 308-316.

Pusztai A, Greer F \& Grant G (1989) Specific uptake of dietary lectins into the systemic circulation of rats. Biochemical Society Transactions 17, 481-482.

Restum-Miguel N \& Prouvost-Danon A (1985) Effects of multiple oral dosing on IgE synthesis in mice: oral sensitization by albumin extracts from seeds of Jack fruit (Artocarpus integrifolia) containing lectins. Immunology 54, 497-504.

Ryan JJ (1997) Interleukin-4 and its receptor: essential mediators of the allergic response. Journal of Allergy and Clinical Immunology 99, 1-5.

Snapper CM \& Paul WE (1987) Interferon-gamma and B cell stimulatory factor-1 reciprocally regulate Ig isotype production. Science 236, 944-947.

Strobel S (1991) Mechanisms of gastrointestinal immunoregulation and food induced injury to the gut. European Journal of Clinical Nutrition 45, 1-9.

Strobel S \& Mowat AM (1998) Immune responses to dietary antigens: oral tolerance. Immunology Today 19, 173-181.

Stokes CR, Newby TJ \& Bourne FJ (1983) The influence of oral immunization on local and systemic immune responses to heterologous antigens. Clinical and Experimental Immunology, 52, 399-406.

Watzl B, Neudecker C, Hänsch GM, Rechkemmer G \& PoolZobel BL (2001) Dietary wheat germ agglutinin modulates ovalbumin-induced immune responses in Brown Norway rats. British Journal of Nutrition 85, 483-490. 